\title{
El Ramo del cacao. Exilio, pobreza y lealtad de los inmigrantes venezolanos en Puerto Rico, 1813-1873
}

\author{
por \\ Alejandro Cardozo Uzcátegui ${ }^{1}$ \\ Universidad Sergio Arboleda, Bogotá
}

Los objetivos de este trabajo han sido determinar los testimonios de fidelidad venezolana a la corona, las causas que motivaron un exilio tan numeroso y atropellado, así como las condiciones politicas y administrativas con que fue recibida esta diáspora en Puerto Rico. Las fuentes fueron la colección del Archivo Histórico Nacional (Madrid) de Ultramar (1070 y 1111) que contiene expedientes, cartas y memoriales de exiliados, prensa y oficios. Los resultados fueron demostrar el compromiso de España con los fieles vasallos venezolanos, la tragedia y vulnerabilidad en particular de las mujeres de la diáspora y los mecanismos político-administrativos (el Ramo del cacao) de España para enfrentar el problema social de la migración masiva de venezolanos en Puerto Rico.

Palabras clave: Ramo del cacao; guerra; diáspora; exilio; Costa Firme; Venezuela.

Cómo Citar Este Artículo / Citation: Cardozo Uzcátegui, Alejandro, "El Ramo del cacao. Exilio, pobreza y lealtad de los inmigrantes venezolanos en Puerto Rico, 1813-1873", Revista de Indias, LXXXI/282 (Madrid, 2021): 473-501. https://doi.org/10.3989/revindias.2021.014.

\section{INTRODUCCIÓN}

Puerto Rico y Curazao fueron los dos destinos naturales para los exiliados venezolanos durante la Guerra de Independencia. El lugar más violento de toda la América española, durante el conflicto, fue la provincia de Venezuela.

\footnotetext{
${ }^{1}$ alejandro.cardozo@usa.edu.co, ORCID iD: https://orcid.org/0000-0002-4461-3285
} de uso y distribución Creative Commons Reconocimiento 4.0 Internacional (CC BY 4.0). 
Aunque se registran casos más tempranos, los leales al gobierno del rey comenzaron a emigrar desde 1813 para Curazao y Puerto Rico por la proximidad de estas islas a los principales puertos venezolanos: Puerto Cabello y $\mathrm{La}$ Guaira. No obstante, la isla de Puerto Rico por ser dominio español tenía significación especial como destino final para el exilio de los venezolanos realistas, el destierro allá tenía implicaciones políticas y administrativas diferentes que en cualquier otra isla caribeña. En Puerto Rico el rey podría encargarse de sus súbditos fieles, que perseguidos en Costa Firme por los patriotas, viajaron en condiciones precarias, abandonando propiedades, bienes y fortuna en Venezuela ${ }^{2}$.

En este estudio analizamos la política administrativa con que la corona se hizo cargo de sus súbditos fieles: el llamado Ramo del cacao - también conocido como el Fondo del cacao - fórmula tributaria con la que el gobierno español logró atender una oleada migratoria para la cual la isla de Puerto Rico no estaba preparada. El Ramo del cacao será un ámbito que va más allá de lo administrativo y tributario; también será político, pues se trataba de la forma en que el sistema monárquico español compensaba, en la medida de la tragedia del destierro, la lealtad de sus súbditos. En todas las instancias analizadas en la documentación, los exponentes descargan una retórica de fidelidad, amor y entrega a la causa del rey, que hemos detectado como una fábula noble y leal para probar el apego al sistema y su desgraciada situación: «El mucho tiempo transcurrido desde la evasión de aquel país [Venezuela] por nuestras tropas, y el entrar en condiciones con el Soberano desde país que sí reconoce la suave y justa mano de la dominación española [Puerto Rico]» ${ }^{3}$, como escribía Manuel Sojo en 1834; o Plácido Arrizurrieta quien «ha mani-

${ }^{2}$ La historiografía sobre las migraciones en Puerto Rico, en buena medida, ha dejado de lado el fenómeno de la migración «interimperial» a la isla, como el caso de los venezolanos leales al sistema español que huyeron de la guerra y las persecuciones de Costa Firme desde 1812. Ha habido abundantes trabajos a partir de 1960 sobre migraciones a Puerto Rico (entre ellos los de Estela Cifre), así como estudios estadísticos y cronológicos - 1800-1830 - (Marazzi, 1974), de inmigración italiana (Hernández, 1976) y corsa (Luque, 1986), o los inmigrados franceses tras la independencia y fundación de Haití (Luque, 1987-1988). El V Centenario del Descubrimiento de América acarreó una producción importante de estudios sobre circuitos de migración peninsular hacia Puerto Rico: González (1993), Cubano (1993), Sonesson (1995), Pérez (1996), Segura (1997) y, sin embargo, el fenómeno de movimientos migratorios caribeños, por causa de las revoluciones atlánticas, hacia los territorios todavía leales a España - como Puerto Rico- aún no abundan. En tal sentido, debemos hacer la referencia del libro de Marco Tulio Mérida, Emigración de Venezuela a Puerto Rico tras la Ruptura Colonial (2006). Y para un balance de este estado del arte: Naranjo y García: 2000: 161-196.

${ }^{3}$ Expediente de Don Manuel Sojo, 14 de diciembre de 1834, Archivo Histórico Nacional (AHN), Ultramar, 1070, exp. 13, núm. 1 recto. 
festado siempre la más decidida adhesión a la Monarquía Española [...] sufrió terribles persecuciones de los disidentes por no querer sucumbir al sistema revolucionario» ${ }^{4}$, o esta joya retórica: «¿Y es posible Señor que a la exponente privada de todo recurso no se le haya concedido este corto auxilio [la pensión del Ramo del cacao], sobreviviendo la autoridad a la indigencia de la lealtad $»^{5}$, de Josefa Muñoz, emigrada de 1828.

Así como la Real Hacienda velaba por el cumplimiento de las exigencias para optar a la pensión del Ramo del cacao, también esto dio para otro importante fenómeno, la lucha entre el capitán general de Puerto Rico y el intendente, que en varios casos se enfrentaron por el criterio de concesión de la pensión del cacao para los exiliados venezolanos. En la casuística estudiada veremos como el capitán general intenta beneficiar a la mayor cantidad de exiliados, mientras el intendente, por su parte, procura limitar los socorros, argumentando siempre la cuestión del estado de las Cajas Reales de la isla, los procesos viciados y la tolerancia migratoria: ¿hasta dónde se van a aceptar y auxiliar las familias llegadas de Costa Firme?

Esto nos conduce a un debate que se dio en el Consejo Real sobre las decisiones que podían afectar a la opinión pública de España, que decide abandonar —o no- a sus súbditos más leales, así como argumentos de índole moral sobre la responsabilidad ilimitada del rey sobre estos vasallos desterrados y, obviamente, el aspecto meramente económico de la sustentabilidad de las ayudas una vez que la crisis económica e inflacionaria en el propio Puerto Rico merme cada vez más el tesoro español en la isla. Sin embargo, el balance general de este debate resulta en que España acarrea con sus leales súbditos venezolanos hasta los años sesenta del siglo XIX, haciéndose responsable de los vasallos emigrados de una guerra librada hace más de treinta años.

Asimismo, podremos comprender el relato de la mujer como sujeto activo tanto en el proceso de la guerra como de la diáspora. El análisis del Ramo del cacao enfoca primordialmente a los exiliados más afectados por el conflicto, los más vulnerables, quienes migraron apenas con lo que traían puesto, por lo cual la mujer será visible en esta documentación como la protagonista de una dinámica de exilio y supervivencia.

${ }^{4}$ Solicitud de pensión de Don Plácido Arrizzurrieta al Capitán General de Puerto Rico, 8 de enero de 1838, AHN, Ultramar, 1070, exp. 6, núm. 2, 5 verso.

5 Sobre los padecimientos de Doña Josefa Muñoz en esta Isla desde su llegada de Costa Firme, 3 de marzo de 1828, AHN, Ultramar, 1070, exp. 12, núm. 12, 2 recto. 


\section{EL RAMO DEL CACAO}

El Ramo del cacao fue el fondo de pensiones y ayudas para los exiliados venezolanos en Puerto Rico que lograban probar por medio de expedientes su lealtad al gobierno del rey y al sistema monárquico, así como demostrar su situación de privación económica. Al principio se denominó a esta ayuda «socorros», más tarde se nombró como las «pensiones de gracia» ${ }^{6}$. La documentación refiere indistintamente al Ramo o Fondo del cacao. Estas pensiones se satisfacían del importe de su impuesto de un peso fuerte con que se gravó la fanega de cacao que entraba a Puerto Rico procedente de Venezuela. Durante la primera fase del conflicto (1811-1812) el comercio del cacao prosperó ${ }^{7}$ dado que las importaciones de Puerto Rico de otras zonas costaneras del Caribe como la provincia de Venezuela, se incrementaron precisamente por la guerra, puesto que Cádiz restringió su comercio temiendo otro bloqueo (como el de 1810-1812), el cerco francés de 1812 y la propia inestabilidad política de América. Al mismo tiempo las primeras oleadas migratorias (1813), precisamente por ser las iniciales, recibieron mayor atención presupuestaria.

La primera referencia sobre el mecanismo de pensiones y socorros del Ramo del cacao la obtenemos de José Domingo Díaz (exiliado venezolano, polígrafo, médico, segundo intendente de Puerto Rico en 1822, leal a la corona hasta su muerte) quien escribe al rey que en «1813 refluyeron a esta isla algunos emigrados de Venezuela con motivo de la bárbara ocupación de aquellas provincias por el sedicioso Bolívar» ${ }^{8}$. Para su auxilio la Intendencia estableció el derecho de un peso fuerte por cada fanega de cacao introducida. Costa Firme fue recuperada en 1814 por las armas de S. M. y cesó de cobrarse momentáneamente el impuesto. Díaz explica que en vista del crecimiento de los emigrados de Venezuela y para «atender a tantos clamores, desgracias y miserias» se restableció el peso abolido en 1822 justamente cuando él entró al cargo de intendente en Puerto Rico.

José Domingo Díaz plantea que el impuesto del Ramo del cacao, antes de la emergencia de los exiliados de Venezuela, estaba destinado para el pago de transporte de oficiales y empleados emigrados de Cuba y de la Península «pero

${ }^{6}$ Reseña histórica de este importante asunto de estos socorros y pensiones de gracia, 9 de junio de 1870, AHN, Ultramar, 1111, exp. 17, núm. 1, 48 recto.

${ }^{7}$ Las medidas bélicas y comerciales del bloqueo a Venezuela por parte de la Regencia no afectaron a Coro ni a Maracaibo, por lo que el comercio de cacao tuvo que dinamizarse en esos dos puertos privilegiados, sobre todo Maracaibo que poseía una estructura portuaria. El bloqueo fue suspendido después de la caída de la I República en 1812. Lomabardi, 2006: 72.

${ }^{8}$ El Intendente José Domingo Díaz a S.M. sobre los emigrados de Costa Firme, 3 de julio de 1822, AHN, Ultramar, 1111, exp. 18, núm. 14, 1 vuelto. 
nunca al socorro de particulares que no tenían un derecho legal, sino les era concedido por la beneficencia de S.M $\gg$.

Los expedientes de los exiliados que esperaban beneficiarse de la pensión de gracia debían tener testigos de peso en sus instancias, asimismo, demostrar un estado de necesidad y probada fidelidad al rey. En estos despachos figuran testigos como Domingo de Monteverde, José Tomás Boves, hasta oficiales menores del ejército español que dan cuenta, si es el caso, de que el interesado prestó ayuda económica al ejército realista o, en efecto, luchó en sus filas. De la misma forma, figuran como candidatos a la pensión esposas, hermanos o hijos de oficiales realistas muertos en el combate. Pedro José González, por ejemplo, era caraqueño emigrado a Puerto Rico, argumentaba que su padre, el capitán José González fue «asesinado por los disidentes, y sido consignado él mismo al presidio de Cartagena por sospechas de correspondencia con D. José Antonio Arizabalo, comandante de las tropas realistas que operan en los Llanos de Caracas ${ }^{10}$. También era válido como argumento dentro del expediente haber sido perseguido por sus demostraciones públicas de lealtad al rey, tal como es el caso de las hermanas Rojas Queipo:

\begin{abstract}
Ella [Bárbara Queipo] se manifestó desde el año mismo de la revolución del año de 1810: bien notorio fue entonces, lo es y será siempre que fueron perseguidas hasta lo último, de todas maneras, hicieran ser encerradas en un oscuro calabozo once meses y días, sufriendo no tan solo hambre, desnudez y desprecios, sino golpes de mano y próximas a perder hasta la vida, nunca mencionaron consuelo sin otra causa ni motivo que el ser contrariamente fieles, y adictas a V.M. habiendo obtenido el rescate cuando abandonada la ciudad por los comienzos, se posicionaron de ella las armas de V.M. al mando del Sr. Comandante General D. José Tomás Boves ${ }^{11}$.
\end{abstract}

El Ramo del cacao no solo se ocupó de los casos de persecución ideológica (de quienes manifestaban públicamente en Costa Firme su lealtad al rey), de veteranos del Ejército realista (o parentesco con sus oficiales), también intentó dar soluciones - en ocasiones - a deudas de las cajas reales de la provincia de Venezuela, que una vez desmanteladas en 1821, desconocía a los acreedores venezolanos en Puerto Rico por las «órdenes vigentes sobre iguales créditos prohibiendo su reconocimiento y abono por las cajas de estas

${ }^{9}$ Idem.

${ }^{10}$ Expediente de Pedro José González para pedir un socorro, 4 de julio de 1829, AHN, Ultramar, 1070, exp. 13, núm. 2, 1 recto.

${ }_{11}$ Expediente de las hermanas Rojas Queipo avecindadas en esta Isla, 28 de abril de 1829, AHN, Ultramar, 1070, exp. 13, núm. 2, 1 vuelto. 
Antillas» ${ }^{12}$. Aunque eran casos más complicados de aprobar, algunas veces el procedimiento fue pensionar al acreedor $-\mathrm{O}$ a su viuda - en vista de su situación de pobreza y su imperativa y verificable adhesión a la corona.

También se registran situaciones mixtas, como la de Pedro García Alonso quien era español (de Soria) y se presentó en la Intendencia de Puerto Rico en 1834 exponiendo sobre los socorros que «prestó a nuestro ejército y los padecimientos que sufrió con su esposa D. ${ }^{a}$ Xaviera Calderón [venezolana] hasta el caso de haberle los disidentes subastado los bienes que le encontraron cuando le prendieron por su adhesión al legítimo gobierno» ${ }^{13}$, por lo que pedía que le asignaran una cuota de los fondos del cacao. La respuesta del gobierno fue que «Muy propio era que Alonso siendo europeo siguiese en el año de 1821 el pabellón nacional con los demás emigrados, y no que en 1834 solicitase pensión por haber permanecido en la isla holandesa de Curazao hasta el de 1833 que se presentó en esta plaza» ${ }^{14}$. En esta situación se mezcla el hecho de la nacionalidad de Alonso, por lo que se esperaba de él una lealtad natural, no era meritorio exponerla: si era español no tenía por qué alabar su decisión política, esto se une, a su pesar, con el hecho de que su expediente demuestra que permaneció en territorio extranjero más de una década tras la disolución del nexo colonial.

\section{Un límite al Ramo del cacao}

Las Cajas Reales de Puerto Rico tuvieron que colocar un dique a las exigencias de los emigrados que cada vez demandaban más cobros del Ramo del cacao. El derecho a las pensiones del Ramo cesó por la Real Orden del 3 de julio de 1835, sin embargo quedaba en potestad de la Real Hacienda o del Consejo Real delimitar el goce del derecho hasta la muerte del pensionado, con la prohibición de heredar la gracia a sus deudos, pues «no son de acordarse nuevas [pensiones] porque algún término ha de tener la emigración $\rangle^{15}$. Aunque nunca terminaron de cerrar de un todo las adjudicaciones de las gracias del cacao, pues venido un nuevo caso, dependiendo de cómo se exponía

12 Situación sobre varios acreedores de las Cajas Reales de Puerto Cabello, 26 de mayo de 1851, AHN, Ultramar, 1111, exp. 5, núm. 2, 1 recto.

13 Pedro García Alonso sobre los méritos y servicios prestados por él y por su difunta esposa a una división del Ejército del Rey y otros servicios, 25 de diciembre de 1837, AHN, Ultramar, 1070, exp. 20, núm. 3, 1 verso.

${ }^{14}$ Idem.

15 Ibidem, 2 recto. 
y hasta qué instancia lograba llegar, flexibilizaba a las autoridades para una nueva concesión.

La razón que comprendieron las autoridades españolas en Puerto Rico fue que en un principio se concedieron pensiones sin prever que la migración continuaría y aumentaría. En 1839 se discutió la crisis devenida por la Comisión Consultiva del Ministerio de Hacienda y de Presupuesto, así como por el Consejo de Ultramar dictaminándose la Real Orden de 17 de junio de 1839 para suspender el pago de la gracia el 31 de diciembre del mismo año ${ }^{16}$.

Se decidió que únicamente se invirtieran 2.000 pesos anuales en el Ramo del cacao para conservar algunas pensiones de 6 pesos mensuales para quienes realmente hubieran contraído servicios ejemplares en favor de la metrópoli. Asimismo, se estableció que las pensiones eran intransferibles una vez que moría el beneficiario. Estas medidas se consideraron (en 1839) temporales mientras se dictaminara por ley una resolución definitiva. Así funcionaron las pensiones por el Ramo del cacao hasta que en 1852 se dispuso que siempre que hubiera vacantes, dentro del presupuesto de los 2.000 pesos, se adjudicaba un nuevo beneficiario. Para que esto ocurriera debía salir publicado en la Gaceta Oficial de Puerto Rico previendo que en un tiempo determinado se postularan los interesados que se creyeran con derecho al socorro, siendo emigrados de Venezuela ellos mismos, no sus padres o parientes ${ }^{17}$.

Así continuó el sistema de adjudicación y pagos del Ramo del cacao hasta 1869 cuando el gobernador de Puerto Rico decidió terminar por completo con estos auxilios por medio del decreto del 24 de abril del mismo año en el que se suspendieron los pagos de 5 y 6 pesos mensuales. Esto supuso un grave problema dado que se corría el riesgo de dejar en la indigencia a los beneficiarios por lo que desde Puerto Rico instaban al rey a recoger la medida. Estamos hablando que después de cincuenta años de atención a los exiliados de Costa Firme, España todavía estaba atenta al devenir para lo malo y para lo bueno de estos leales súbditos.

La reflexión de las autoridades españolas en 1870 era que si continuaba la política de estas pensiones de gracia «serán eternamente una carga para las cajas de Puerto Rico [sin embargo] Por un sentimiento de humanidad y gratitud hacia los emigrados de Costa Firme y Venezuela que abandonaron su patria y bienes de fortuna para probar su adhesión a la Metrópoli refugiándo-

${ }^{16}$ La Comisión Consultiva del Ministerio de Hacienda y de Presupuesto al Intendente de Puerto Rico sobre la Real Orden del 17 de junio de 1839, AHN, Ultramar, 1111, exp. 17, núm. 1, 48 verso.

${ }_{17}$ La Intendencia General de Hacienda sobre nuevas adjudicaciones, 24 de abril de 1869, AHN, Ultramar, 1111, exp. 17, núm. 1, 50 verso. 
se en Puerto Rico, se dispuso se les diera algún socorro para evitar que perecieran de miseria ${ }^{18}$.

En este momento ya estamos ante una evolución del Ramo del cacao; no se habla de este sistema de pensiones (en 1870) como el Ramo o Fondo del cacao, pero obviamente se trata de su transformación administrativa pues atiende al mismo tipo de personas que en sus inicios acogió este fondo, son los mismos casos de exiliados de Venezuela.

R. de Mazón, el funcionario que firma el documento, buscaba una solución para no dejar desamparadas a estas personas sobrevivientes del exilio venezolano en Puerto Rico. Propuso que las pensiones que venían disfrutando los emigrados de Venezuela a cuenta de un presupuesto de 10.000 pesetas, continuaran por las Cajas de Puerto Rico; ahora sí que serán intransferibles si la persona muere o varía de estado (casarse, por ejemplo); la Intendencia General de Hacienda publicará semestralmente una relación de pensionistas, estado, edad y cantidad de dinero percibido, acompañado de una fe de existencia expedida por el párroco y por la autoridad local respectiva. Habrá un registro de defunciones de pensionistas ${ }^{19}$.

En 1872 varias pensionistas, todas mujeres, promovieron una instancia para que se les abonase la pensión más los pagos atrasados. Reclamaban los haberes de pagos argumentando que se les dejó de acreditar el dinero por el Decreto del Poder Ejecutivo del 24 de abril de 1869, sin embargo, argumentaron que debían cobrar su dinero con cargo a la Manda Pía Religiosa y arguyen su derecho por tratarse del mismo caso de los emigrados de Venezuela agraciados por el Ramo del cacao. El Negociado $2 .^{\circ}$ en Contabilidad, en la metrópoli, apoyó su solicitud ${ }^{20}$. Esto último comprueba el hecho de que España medio siglo después siguió asumiendo una carga administrativa y ciertamente arrogándose un rol de carácter político respecto a los emigrados venezolanos en Puerto Rico. La lealtad de estos fue atendida, evidentemente, con una observancia e interés muy sugerente por su extensión en el tiempo.

\section{La situación económica (y política) de Puerto Rico y la cuestión del Ramo del cacao}

Cuando la llegada de la primera oleada de la diáspora venezolana a Puerto Rico la situación económica en la isla era complicada, padecía una inflación

\footnotetext{
18 Ibidem, 52 recto.

19 Ibidem, 54 recto.

${ }^{20}$ Ibidem, 57 recto.
} 
sin precedentes. Informaba el intendente de Puerto Rico en 1814 que no tenía como pagar las tropas en un mes, el papel moneda había perdido $300 \%$ de su valor y «los víveres a los precios más altos y desconocidos $»^{21}$. Además de lo que iba a significar para las Cajas Reales puertorriqueñas la migración del exilio venezolano, desde la misma Costa Firme el intendente en Puerto Cabello le pedía a su par en Puerto Rico ayuda (25 fanegas de semillas de tabaco, remesas de harina de trigo y arroz) para reanimar la provincia tras la razia de la guerra de Boves y Bolívar. En una narrativa aguda, remata el intendente Ramírez sobre el esfuerzo que hará desde Puerto Rico para acoger a los primeros exiliados y al mismo tiempo auxiliar a la Costa Firme: «Mi deseo de que contribuyan estos trabajos al restablecimiento de la tranquilidad y a los sabidos afectos de lealtad y vasallaje en la desgraciada Costa Firme, hoy teatro de horrorosas escenas, muy semejantes a las de la parte francesa de la isla de Santo Domingo» ${ }^{22}$. Tal era el paisaje de desolación en Venezuela que al intendente Ramírez le valió compararla con la Guerre des Couteaux haitiana (1799-1801), uno de los episodios más brutales de América ${ }^{23}$.

El 12 de mayo de 1837 se estableció una comisión mixta de examen de pensiones de la cual saldría su arbitrio decidir sobre nuevas asignaciones y socorros hospitalarios para analizar todos aquellos nuevos expedientes que dependieran de «relaciones políticas, posición material de cada individuo, relaciones con el país que abandonaron, y de otras circunstancias que no están ni pueden estar al alcance de la referida Comisión, por cuyas razones no puede clasificarlas $\rangle^{24}$.

La Comisión Auxiliar Consultiva argumentaba que Puerto Rico (1839) ya hacía la contribución extraordinaria de guerra (10.000.000 de reales de vellón) como para sumarle el gasto extraordinario del socorro de los exiliados leales de Costa Firme. Además, la isla estaba padeciendo un nuevo proceso inflacionario, por lo que tenían «que extinguir una considerable cantidad de papel moneda creada en el tiempo del intendente Alejandro Ramírez, y que existiendo allí un cáncer con la moneda llamada macuquina que por su forma $\mathrm{y}$ mala calidad sufre un descrédito de una quinta parte de su valor nominal $»^{25}$, ante la espiral inflacionaria y de devaluación el gobierno tarde o temprano

${ }^{21}$ Oficio del Intendente Alejandro Ramírez a los Ministros en Costa Firme, 4 de febrero de 1814, AHN, Ultramar, exp. 18, núm. 2, 1 vuelto.

22 Ibidem, 2 vuelto.

${ }^{23}$ Yacou, 1996: 277-293.

${ }^{24}$ La Comisión de exámenes de pensiones, 12 de mayo de 1837, AHN, Ultramar, 1111, exp. 17, núm. 1, 39 vuelto.

${ }_{25}$ La Comisión Auxiliar Consultiva al Intendente, 1 de noviembre de 1839, AHN, Ultramar, 1111, exp. 17, núm. 1, 32 vuelto. 
debía recoger ese circulante para detener la crisis de numerario y detener el ciclo de inflación, para ello tendrá que inyectar nuevos dineros una vez depurado el sistema de la dañina moneda macuquina, trance que «su final resultado siempre ha de pesar sobre aquellos naturales ${ }^{26}$.

Para afrontar la complejidad de esta crisis la Comisión Auxiliar Consultiva aconsejó: 1) Deben cesar a partir del 1 de septiembre de 1839 las pensiones y socorros temporales «que hasta ahora han disfrutado los emigrados de ambos sexos de cualquier punto del continente americano» ${ }^{27}$; 2) Que se mantenga el impuesto de un peso fuerte sobre la fanega de cacao hasta que reintegre a las Cajas Reales de Puerto Rico el gasto destinado en dichos socorros; 3) Que el intendente, una vez satisfechas las Cajas Reales, suspenda el impuesto del cacao.

Estas medidas generaron controversia entre las comisiones consultivas y de presupuestos ante las pensiones que los últimos llamaron de «justicia», por lo que la Sección de Presupuestos recomendaba volver a examinar la decisión. Esta Sección respondió a la propuesta de las tres medidas que se debía tener en cuenta que suspender el pago de las pensiones traería un profundo impacto, un «trastorno» en gran número de familias, por lo que convendría prorrogar aquellas medidas hasta que estas familias tuvieran otro medio de subsistencia; la Sección de Presupuestos estaba al tanto de que todas esas familias podían ser merecedoras - o no- de la ayuda, empero los enfermos y ancianos perecerían con semejante disposición, lo que podría traer consecuencias insospechadas para Puerto Rico. Todos en el gobierno sabían que hubo vicios en los precedentes de muchas concesiones de la gracia devenida del Ramo del cacao, a la vez estaban al tanto que «las circunstancias en Venezuela han mejorado en favor de los que emigraron, y que han tenido tiempo para procurarse su subsistencia sin continuar grabando al Tesoro $»^{28}$. Esto nos conduce por varios caminos, por un lado el gobierno español preveía una situación política más que económica respecto al pago de las pensiones del Ramo del cacao: no podían permitir ninguna clase de desorden social devenido de un problema de seguridad pública, ancianos pobres y viudas desvalidas deambulando como fantasmas hambrientos por las calles de San Juan era un escenario que se debía evitar a pesar de la salud de las cajas de Puerto Rico. Por otro lado, la reflexión de las autoridades españolas sobre que las cosas en Venezuela estaban mejor, se refiere a las nuevas políticas migratorias del gobierno de José Antonio Páez (1839-1843) para atraer tanto a mano de obra española, como inversionistas y capitales exiliados con algunas familias desterradas por lo que el clima de persecución política,

\footnotetext{
${ }^{26}$ Idem.

27 Ibidem, 33 recto.

${ }^{28}$ Ibidem, 35 recto.
} 
secuestro de propiedades e intolerancia política había sido superado ${ }^{29} \mathrm{y}$, aunque muchas familias exiliadas podían valerse de ese nuevo contexto en su antigua tierra, para desgravar ese peso del Tesoro español, estaban al tanto en la Sección de presupuestos que era preferible cargar con ese peso que afrontar una súbita situación de desorden y rebelión.

La Sección de Presupuestos asimismo alegaba que «El socorro de los emigrados era una obligación del Estado y no de la isla. Por un principio equivocado y por la costumbre de imponer contribuciones para cualquiera gasto ${ }^{30}$ se estableció el impuesto del cacao. Eran críticos con el origen de esta medida por considerarla dentro del esquema de finanzas, impulsivo y precipitado, que de hecho se abrogó desde un principio potestades que no le correspondía a la política económica de la isla ni a sus autoridades. No obstante, había que estar en el año de 1814 recibiendo en Puerto Rico una diáspora de casi 1.000 refugiados de guerra, en desnudez y total estado de pobreza, como lo expresó en su momento el intendente Alejandro Ramírez «¿Cuáles arbitrios podrá contar, viniendo de un golpe el gran número de personas refugiadas [de Venezuela] y siendo este un país [Puerto Rico] sin capitales, sin vecinos pudientes, una plaza permanente militar, y una tesorería sin crédito, por sus grandes empeños y deudas de tiempos anteriores, y por ser sus gastos fijos muy superiores a sus ingresos? $\wedge^{31}$

La discusión del presupuesto en relación a las gracias devenidas del Ramo del cacao tardará mucho en definirse, en dar una resolución final - podemos aseverar que nunca terminó de darse - pues fue un péndulo, como hemos señalado antes, entre la cuestión moral y política y la realidad económica, en donde a veces el primer asunto era más «real» que el segundo, es decir, donde la cosa política tras una decisión, tenía más peso que los números rojos del Tesoro. Por ejemplo, después de este debate de 1839 se autorizó al intendente suspender el pago de pensiones para el 31 de octubre de ese año, sin embargo, se le autorizó disponer de 2.000 pesos fuertes anuales para mantener pensiones de 6 pesos mensuales «a los individuos que realmente hubieren contraído méritos especiales en favor de la Metrópoli por sí, sus padres o maridos ${ }^{32}$ y que por razones de salud o edad no puedan procurarse ningún oficio remunerable. Estas medidas serán interinas hasta la resolución de las

29 Lynch, 2001: 115-116.

${ }^{30}$ La Sección de presupuestos sobre las medidas de la Comisión Auxiliar Consultiva, AHN, Ultramar, 1111, exp. 17, núm. 1, 35 vuelto.

${ }_{31}$ Carta del Intendente de Puerto Rico Alejandro Ramírez, 6 de septiembre de 1814, AHN, Ultramar, 1111, exp. 18, núm. 2, 2 recto.

${ }^{32}$ La Comisión Auxiliar Consultiva, 2 de diciembre de 1840, AHN, Ultramar, 1111, exp. 17, núm. 1, 41 vuelto. 
Cortes, y además que se le proponga a las Cortes la supresión del derecho sobre el cacao. La mesa de la Sección de Presupuestos respondió que había que extender el plazo de la suspensión de pagos para quienes podían valerse por sí mismos de la fecha propuesta (octubre) a diciembre de 1839. También dio un giro total a la cuestión del otorgamiento de las pensiones: que fuera transferible, aunque no heredable, una vez muerto el beneficiario anterior, se hiciera público para «ofertar» la pensión a un nuevo emigrado - no familiar ni pariente- en situación de pobreza absoluta. Aunque estas medidas ya la hemos mencionado, vale subrayar que este debate se extendió - entre la Sección de Presupuestos, el intendente y la Comisión Auxiliar Consultivapor 12 años. La intención de recalcar estos hechos es mostrar la naturaleza pendular en la toma de decisiones sobre una circunstancia que fue extremadamente sensible en lo político y moral, sobrevolando las gravísimas condiciones presupuestarias del Tesoro español.

A manera de colofón de este apartado, merece mencionarse una brevísima casuística para comprender hasta dónde llegó esta relación de lealtad y compromiso (político, moral y administrativo) con los súbditos fieles de Venezuela. El 30 de abril de 1870 Luis Becerra a nombre de Margarita Ferrán y María Asunción Pimentel y «varias otras de Puerto Rico, que cobraban una pensión de 5 a 6 pesos mensuales por el estado triste y miserable en que llegaron de Venezuela, de donde emigraron por seguir la bandera española ${ }^{33}$, levanta un expediente respecto a la pensión sobre el Ramo del cacao que las mencionadas mujeres dejaron de percibir, por lo que ellas piden se les autorice de nuevo el cobro. Más adelante se suman instancias idénticas de Josefa Guerrero y Flores y M. ${ }^{a}$ del Carmen y Mercedes Flores: «Recurren a este ministro treinta y un huérfanas y viudas en solicitud de que quede sin efecto la orden de suspensión de las pensiones que disfrutaban» ${ }^{34}$, la cuestión pendular que oscilaba entre medidas de recorte presupuestario y medidas de contención política, que inferimos, fue una situación indefinible hasta la muerte de la última hija del exilio, la última hija del cacao.

El RELATO DE LA MUJER EN EL EXILIO: PROTAGONISTA Y SUPERVIVIENTE

La mujer en este período de la historia española, venezolana y puertorriqueña será en buena medida la protagonista del proceso. Los acontecimientos

${ }^{33}$ El intendente sobre varias mujeres emigradas de Costa Firme, 30 de abril de 1870, AHN, Ultramar, 1111, exp. 17, núm. 1, 46 recto y 46 vuelto.

${ }^{34}$ Ibidem, 47 vuelto. 
en Costa Firme, como hemos planteado varias veces, serán los más violentos en el transcurso de las guerras de independencia de América $^{35}$, especialmente desde el decreto de Guerra a Muerte (1813) hasta el Tratado de Armisticio y Regularización de la Guerra, conocido también como el Armisticio de Trujillo (1820). Será el período de la diáspora de los venezolanos que se refugian bajo la protección del rey en el territorio español más próximo, Puerto Rico. En este sentido, como ya hemos acotado, las situaciones de extrema vulnerabilidad eran las que más se atendían por el Ramo del cacao, por ende, la mayor parte de ese registro será mujeres: viudas como Rosa de Urloa, que migró a Curazao con dos hijas por «leal y adicta a nuestro legítimo soberano» ${ }^{36}$. Su relato del exilio describe los padecimientos del desamparo inherentes a toda diáspora. Rosa vivió en Curazao la cara más amarga del periplo, pues el drama de huir sola con dos hijas y sin dinero a una isla con idioma y costumbres distintas, fue un choque. Su único hijo varón se ofreció voluntariamente a servir a la causa de Su Majestad, en la división al mando de Antonio Fiscar.

Huérfanas como Timotea y Dolores Cardona intentaron probar por medio de una justificación de testigos que en 1811 «emigraron de Caracas en consecuencia de haberse sublevado aquella ciudad contra la Madre Patria ${ }^{37}$. Es llamativa la visión de la rebelión de las hermanas Cardona: la ciudad contra el imperio. Quien opuso resistencia a los eventos de 1811, y por ende las expuso al escarnio patriota fue su padre, Sebastián Cardona, acabando sus días perseguido y arrestado. Siguiendo los pasos de su padre se granjearon la enemistad y el desprecio de muchos en Caracas. Las vejaciones sufridas por Sebastián le costaron la vida. Las hermanas, enemistadas, mal vistas y señaladas decidieron emigrar a Puerto Rico donde las recibió y protegió el coronel Pedro Tomás de Córdoba, a la sazón secretario de la Capitanía General puertorriqueña. En 1836 se fueron con su protector a España pero no se aclimataron y enfermaron, situación que obligó su retorno. El regreso a Puerto Rico

${ }^{35}$ La naturaleza de la represión de los patriotas por la fidelidad monárquica es muy cambiante en América. En relación a la vida familiar, por ejemplo, el caso de la prohibición de las señoritas cordobesas (Argentina) de casarse con españoles peninsulares que no poseyeran carta de ciudadanía, por una resolución dada en Buenos Aires el 11 de abril de 1817. Llama la atención la naturaleza discriminatoria de esta orden: solo se aplicaba a mujeres blancas criollas, pues los varones criollos sí podían contraer matrimonio con españolas, es decir, aplicaba un criterio de diferenciación de casta y de género. Ghirardi, 1998: 125-126.

${ }_{36}$ Documento probatorio de $D^{a}$ Rosa de Urloa firmado en Maiquetía por D. Domingo de Monteverde, 2 de diciembre de 1815, AHN, Ultramar, 1070, exp. 11, núm. 13, 1 recto.

37 Instancia de Timotea Cardona y Dolores Cardona al Intendente de esta Isla, AHN, 19 de abril de 1839, Ultramar, 1070, exp. 21, núm. 1, 1 recto, 1 verso. 
supuso alejarse de su protector Tomás de Córdoba, con lo que comenzaría una nueva fase de penurias ligadas, otra vez, a una emigración.

Las decisiones políticas de lealtad monárquica de su padre como de las hermanas, significaron que los «disidentes» secuestraran todos sus bienes en Caracas y los remataran a favor del tesoro de la nueva república, como bien informan las Cardona. Las súplicas de socorro por el Ramo del cacao de las hermanas se extienden hasta 1839, siendo negativa la repuesta a todas sus solicitudes. La última negativa emana de la Sección de Presupuestos de la Real Hacienda ${ }^{38}$.

Mujeres que llevaban consigo niños de parientes que no lograron embarcarse ni sobrevivir el embate del exilio, como las ya citadas hermanas Rojas Queipo. Bárbara y Soledad salieron de Caracas «por su fidelidad y amor a V.M. en mayo de $1821 »$ a la llegada del ejército patriota. Sobrevivieron un año en Puerto Cabello "donde hicieron algo las tropas de V.M.», no lo suficiente, para desgracia de ellas, pues no aguantaron por mucho más tiempo el sitio de Puerto Cabello para padecer situaciones de pobreza, vejaciones y tortura. Refieren las hermanas Queipo al sitio de Puerto Cabello de 1822, evento posterior a la batalla de Carabobo de 1821 cuando tras la derrota los restos del ejército realista se refugiaron en la plaza fortificada del mismo puerto, al tiempo que los republicanos tomaban Caracas (el 29 de junio), Coro (el 25 de julio), Cartagena de Indias (el 10 de octubre) y Cumaná (el 14 de octubre) mientas las fuerzas del rey se resguardaban en Puerto Cabello ${ }^{39}$ esperando recibir el apoyo de Puerto Rico y Cuba ${ }^{40}$. El 24 de julio el capitán general Miguel de la Torre era reemplazado por Francisco Tomás Morales y enviado a Puerto Rico como capitán general de la isla. Narran las Queipo Rojas que perdieron una hermana por las mismas penurias. Otra situación añadida de dificultad era llegar al destino final sin conexiones ni vínculos, sin mapas humanos ${ }^{41}$ para plantear una estrategia de sobrevivencia: «sin recursos, sin amistades, ni parientes, pueden decir que carecen de todo para sobrevivir» ${ }^{42}$.

Abuelas, como María de la Luz Maiz quien refiere un caso mixto, pues solicitaba la gracia de pensión por el Ramo del cacao para su nieta en 1839, aun cuando había emigrado a Puerto Rico en 1821. Alegaba para que su nieta mereciera la pensión una suerte de «transferencia» de méritos: el hecho de

38 Ibidem, 3 verso.

39 Zeuske, 2009: 39-58.

40 Marichal, 1994: 587-613.

${ }^{41}$ Cardozo, 2013: 66.

42 Expediente de las hermanas Rojas Queipo avecindadas en esta Isla, 28 de abril de 1829, AHN, Ultramar, 1070, exp. 14, núm. 3, 1 verso. 
que ella, María de la Luz, había perdido en Venezuela tres haciendas de cacao y cuatro casas por su adhesión al gobierno del rey. Ella vivía con su hija, quien estaba casada con un oficial del Regimiento de Granada por lo que regresaron a España dejándole sola en Puerto Rico a cargo de la nieta ${ }^{43}$.

\section{De mantuanas del rey a indigentes por el rey}

Mujeres que gozaban dentro del gobierno del rey en Venezuela de fortuna y reconocimiento social, por mantenerse leales a España pasaron a un insospechado estado de necesidad. Como Josefa Muñoz quien confiesa jamás haber sufrido hambre y miseria hasta que huyó a Puerto Rico, donde vive «acosada y perseguida de las miserias y hambres en una edad en que las fuerzas se le debilitan $\rangle^{44}$. Su posición en Venezuela tuvo que haber sido privilegiada, su cercanía a las autoridades españolas era patente pues quien le prestó el dinero para emigrar a Puerto Rico fue el mismo Francisco Tomás Morales, el último capitán general de Venezuela y mariscal de campo durante la guerra.

Otra privilegiada del sistema por el cual renuncia a su riqueza y estatus fue Feliciana Frasqueri, viuda de Bernardo Ferrara. Alegaba Feliciana que ella y su esposo habían perdido en Caracas más de 90.000 pesos. Entre otros servicios notables hechos al rey — por lo que expusieron su lealtad monárquica a los patriotas - fue la ayuda dada a las tropas peninsulares de 90.000 raciones de comida, así como 6.000 pesos que prestó en 1814 a José Tomás Boves, «prestando al mismo tiempo cuantos auxilios pudo a los españoles afligidos por los rebeldes que recurrían a su generosidad $»^{45}$. Su estatus mantuano queda en evidencia en su expediente, uno de los testigos que avala su lealtad y adhesión al trono, es el arzobispo de Caracas Narciso Coll y Prat. En su expediente se unen hechos y demostraciones como cuando Ferrara sobornó a unos rebeldes con el fin de sacar de prisión a españoles que solo esperaban la muerte, tal fue el caso del corregidor y teniente de justicia de la Victoria y San Mateo, Juan de la Cruz Mena, quien «puesto en capilla para ser fusilado» en el último momento llegó Ferrara con el dinero para su rescate. Asimismo, Ferrara escondió funcionarios españoles que luego eran

${ }^{43}$ Sobre cesación de pensiones sobre el Ramo del cacao, 3 de marzo de 1839, AHN, Ultramar, exp. 10, núm. 1, 2 verso.

${ }_{44}$ Expediente de $D^{a}$ Josefa Muñoz, 1 de diciembre de 1828, AHN, Ultramar, 1070, exp. 12, núm. 2, 1 recto.

${ }^{45}$ Instancia de $D^{a}$ Feliciana Frasqueri viuda de D. Bernardo Ferrara para solicitar un aumento de su pensión por el Ramo del cacao, 18 de junio de 1847, AHN, Ultramar, 1070, exp. 22, núm. 1,1 verso. 
delatados por «espías de los enemigos», y éste les pagaba los pasaportes para huir a San Tomás.

Estos hechos los certifican en el expediente de Feliciana nadie menos que Coll y Prat (arzobispo) y Francisco Tomás Morales (capitán general). El rico testimonial de Feliciana, sobre las mejores voces monárquicas de la dura época de guerra, infidencias, traiciones y lealtades le proporcionaría a la reina de España (nos situamos en 1839 y 1840) motivos para medir el talante de Feliciana como fiel vasalla de España, y al mismo tiempo indica el contraste entre el goce privilegiado de los Ferrara Frasqueri en la Caracas monárquica y el estado de indigencia de Feliciana en Puerto Rico, pues le dice a la reina que no agrega más testimonios por no poder sufragar un trámite mayor. Ella quiere un aumento en su pensión de 14 pesos a 30 pesos pues como viuda, debe cargar con dos hijas y un hijo paralítico. En 1840 le responden que por la Ley del 26 de mayo de 1835 y el Real Decreto del 12 de mayo de 1837 donde previenen que solo las cortes pueden conceder pensiones, y en el caso de su solicitud, un aumento ${ }^{46}$.

Josefa Pumar mantiene a sus «desamparadas hijas» Gertrudis, Bárbara, Concepción, Francisca, Ana y Rosario en Puerto Rico, exiliada, viuda del capitán realista Francisco de Paula Arteaga, e hija de nadie menos que del vizconde de Pumar y marqués de Masparro, de la nobleza territorial de los Llanos venezolanos, que apenas poco más de una década eran los dueños de la fecundísima ciudad del Barinas, dueños de la tierra donde se dio el origen al tabaco más famoso en Europa durante los siglos XVII y XVIII (el de tipo Varinas). Josefa solicita un aumento de 100 pesos sobre los 25 que percibe del Ramo del cacao ${ }^{47}$.

Las hermanas Casas: Petronila, Dolores, Ignacia, Concepción, Encarnación y Trinidad exponen su caso desde 1813. Hijas de Juan Antonio Casas quien fue administrador de la Renta del Tabaco en Costa Firme, un cargo de alto nivel en la administración del rey. Para comprender la valía de estas huérfanas, ahora exiliadas en Puerto Rico, basta con saber que su expediente llegó a las Cortes de Cádiz (en 1813) por la vía del capitán general de Venezuela Domingo de Monteverde quien apoyó ante la regencia la solicitud de las huérfanas - devengar la mitad del sueldo de su padre fallecido, 1.100 pesos anuales - alegando los servicios de Juan Antonio Casas a la corona, quien fue decapitado por los patriotas en Caracas. Además alegaba el militar

46 Ibidem, 3 recto.

${ }^{47}$ Solicitud de aumento de la pensión de gracia de $D^{a}$ Josefa Pumar, 31 de agosto de 1833, AHN, Ultramar, 1070, exp. 16, núm. 1, 1 verso. 
canario «el estado infeliz en que quedaban las huérfanas en Puerto Rico» ${ }^{48}$. En 1832 solo sobrevivían Ignacia y Concepción, las otras cuatro hermanas ya habían fallecido. A las sobrevivientes se les concedió una pensión de 100 pesos anuales sobre las vacantes mayores y menores del arzobispado de $\mathrm{Ca}$ racas, una fórmula de socorros distinta al Ramo del cacao, vigilada por una «Comisión de premios».

Gabriel de Casas, hermano de las huérfanas, nos narra que ellas emigraron a Puerto Rico esperando un pago de deuda por el orden de los 1.285 pesos, a lo que responde el intendente de la isla que «son los mismos [créditos reclamados] que los de una innumerable multitud de acreedores al Erario» ${ }^{49}$. Esto, sumado a varios otros similares, deja claro lo complicado que era honrar a tantos acreedores de las Reales Cajas de la Provincia de Venezuela, que una vez resuelto el conflicto a favor de la instauración de la República, fueron desconocidos por la desestructuración del aparato administrativo de la corona en Venezuela. Varias reales órdenes, como la citada por el intendente y por el mismo Gabriel, la del 3 de julio de 1831, hacía taxativo el mandato de no pagar esas deudas de Costa Firme por el tesoro de la isla. Por un lado para evitar la corrupción de un trámite que por autonomía y distancia iba a ser irremediable, y por otro para intentar salvaguardar el estado de un tesoro cada vez más estrecho.

El intendente también aclara que a estas hermanas - quienes unas se casaron, otras fallecieron - se les ha satisfecho desde su llegada a la isla, con una pensión de 8 pesos, 2 reales y 22 maravedíes al mes, que no deben pedir aumentos ni otras consideraciones pues han gozado de esta gracia a diferencia de muchos. Eso nos lleva ante este proceso administrativo ciertamente diferente - pues se encontró otro modo de socorro, alternativo al Ramo del cacao, debido a la deuda que contraía las Reales Cajas con ellas y al buen nombre de su decapitado padre - y palpablemente privilegiado: la suerte de una migración más temprana fue mejor desde el punto de vista de los auxilios, desde la perspectiva del compromiso de la corona, y reiterando una idea ya expuesta: el nivel de la tragedia por la fidelidad al rey repuja cualquier expediente: no solo muere degollado el patriarca De Casas, su hijo, Francisco de Casas también fue decapitado por los patriotas ${ }^{50}$.

Asimismo, tuvo mucho que ver la trayectoria de su padre, importante funcionario a quien — como dijimos - le cortaron la cabeza por su lealtad al rey.

48 A los Señores Diputados, Secretarios de las Cortes generales y extraordinarias, 24 de febrero de 1813, AHN, Ultramar, 1070, exp. 27, núm. 1, 1 vuelto, 2 recto.

49 Ibidem, 2 vuelto.

${ }^{50}$ Ibidem, 1 recto. 
Este cargo de administrador de la Renta del Tabaco recordemos que en buena medida a la par del tema tributario, es muy político, con lo cual según el registro de casos que hemos revisado gozaba de más peso - al menos al momento de estas circunstancias de reconocer el mérito y pensionar a sus deudos- que una carrera militar, pues peor fortuna le ha tocado a las viudas e hijas de militares profesionales que la de estos funcionarios y la de presbíteros emigrados. Igualmente tenemos el caso de la viuda Ferrara Frasqueri con quien el intendente se comprometió en avanzar con su caso hasta el final. Pero indudablemente a los deudos de los militares se les trató con menos denuedo.

La viuda del teniente coronel graduado Melchor Hidalgo Yáñez, Micaela Elverdin, solicitaba en 1841 el pago de 4.697 pesos que le debe el Estado por obligaciones contraídas en la provincia de Venezuela, se encontraba al borde de la indigencia por ser criolla casada con un militar español, por lo que se le negó el monte pío militar. Melchor «después de abandonar su país natal siguiendo el pabellón Español casó siendo Yáñez paisano causa que la priva de los beneficios del monte pío, y sin bienes, con hijos que aún no han salido de la infancia, su suerte futura se le presenta muy triste en un país extraño ${ }^{51}$. Todo se le niega, incluso la pensión del Ramo del cacao no parece ser una opción para ella por parte de la administración de la isla.

Igualmente Nicolasa de Jesús Chávez, viuda del subteniente del Batallón de Leales Corianos en el Ejército de Costa Firme Fermín Bermejo. Nicolasa pide en 1839 que le continúen abonando los 8 pesos mensuales, que ahora por Real Orden del 17 de junio del mismo año, le redujeron a 6 pesos mensuales (recordemos que una de las pocas decisiones firmes respecto al Ramo del cacao fue reducir el presupuesto de estos socorros a 2.000 pesos anuales) por tratarse de una ayuda a «los emigrados más pobres y beneméritos» ${ }^{52}$; Nicolasa levanta una solicitud hasta los mismos predios del rey rogándole que se restituya la cifra anterior, pues con esta reducción quedará en una profunda pobreza.

Con Nicolasa no solo se comprenderá la diferenciación de emigrados deudos de militares y de emigrados deudos de funcionarios reales (solo tomamos los más paradigmáticos por la bastedad documental), ni qué decir cuando se comparan los arreglos que hace el gobierno del rey con los emigrados leales nobles

${ }^{51} D^{a}$ Micaela Elverdin solicita a la Intendencia de esta isla se le pague la deuda por no gozar de monte pío militar, 22 de febrero de 1841, AHN, Ultramar, 1070, exp. 24, núm. 2, 1 recto.

${ }_{52}$ El Intendente de Puerto Rico al Consejo Real de Hacienda sobre los emigrados beneméritos de Costa Firme, 19 de diciembre de 1839, AHN, Ultramar, 1070, exp. 30, núm. 2, 1 recto. 
y mantuanos, de pensiones entre los 25 y 50 pesos - como el caso del marqués del Valle, quien devengó 50 pesos mensuales hasta su muerte ${ }^{53}$ — pareados con los 6 pesos de Nicolasa (y la mayoría del exilio venezolano en Puerto Rico); con Nicolasa se entenderá también el relato de la tragedia, que no podemos dejar de lado en este apartado, más que por casuística, para ir comprendiendo a fondo el papel de la mujer en esta historia y en la Historia; que ahora circunstancialmente la vemos protagonizando una tragedia, y por ende es un ser visible y documentable.

La tragedia en la configuración de la cultura política de las mujeres leales: la viuda pobre, la viuda noble

En el caso de Nicolasa de Jesús Chávez encontramos el relato paradigmático de la narrativa de la lealtad y la renuncia «gustosa» por seguir fieles a la Corona «después de aquellas desastrosas pero beneméritas campañas tuvo la honra de seguir a su marido emigrada a esta isla abandonando gustosa su patria e intereses como fiel vasalla de V.M. ${ }^{54}$ En Puerto Rico Nicolasa y su esposo se instalaron en Villa de Arecibo, no en la capital por lo que Fermín, su marido, tuvo que viajar dos veces en busca destino o agregación a algún cuerpo militar. En el último viaje, le escribe Nicolasa a la reina, que su marido fue asesinado y descuartizado, apareciendo a los pocos días en un río, decapitado junto con dos paisanos que le acompañaban. Una situación de violencia de caminos sórdida, sangrienta. Sin embargo, en su relato viene el trato recibido por dos autoridades diferentes, con lo cual se puede inferir la discriminación con que era atendida una viuda de un oficial con tres hijos y el de, por ejemplo, Manuel Cayetano de Monserrate e Ibarra, quien fue secretario de Boves, devengaba 25 pesos mensuales desde su llegada a Puerto Rico.

Dice Nicolasa «Ha practicado algunas diligencias pero siempre ha encontrado la clemencia sorda a sus instancias, sin poder hacer presente su justo reclamo a los demás capitanes generales, ya por no haber venido al campo y ya porque cuando llegó a esta villa el antecesor del digno Conde Mirasol que nos manda, lo hizo con tanta premura que no pudo exponerle la miseria en

53 Pensión aprobada al Marqués del Valle de Santiago, AHM, 30 de julio de 1831, U1tramar, 1111, exp. 16, núm. 2, 1 recto. Al marqués del Valle se le concedió la pensión por 50 pesos y a cada hermano una de 25 pesos, se les concedió aun viviendo en Curazao pero pagaderos al llegar a Puerto Rico.

${ }^{54}$ Ibidem, 1 recto. 
que se encuentra [...] por lo que aprovechando ahora la ocasión de este Señor Capitán General que oye más despacio los lamentos de los pobres, elevo a V.M. por su conducto esta instancia y justa reclamación» ${ }^{55}$.

Nicolasa admite que todas las pruebas de servicio las llevaba encima Fermín cuando fue asesinado. «Rendidamente a suplica como Madre de todos sus súbditos que le han sido fieles y han perdido su subsistencia por seguir las banderas de nuestro augusto Padre, se digne en remuneración y recompensa a los peligros y sacrificios, servicios de mi difunto esposo contraídos en aquel Benemérito Ejército» ${ }^{56}$.

Vayamos al otro extremo de la línea social: Belén Jerez de Aristiguieta pertenece a una de las familias más notables de los mantuanos caraqueños ${ }^{57}$, viuda del coronel de artillería Joaquín Pérez, solicita el abono por las Cajas Reales de Puerto Rico una pensión de 333 pesos, dos maravedíes y medio real que le concedió por la Real Orden del 20 de julio de 1807 sobre las vacantes mayores y menores del arzobispado caraqueño, por haberse casado su esposo con el rango de teniente, Belén quedó sin la opción del monte pío ${ }^{58}$. Tenemos por esta información dos formas, al parecer, para que una viuda quede excluida del monte pío: ser criolla casada con un militar español y que un oficial contraiga nupcias con un rango inferior determinado, en este caso, teniente. Pero más allá de este interludio administrativo respecto al monte pío nos interesa destacar las situaciones diferentes de dos exiliadas venezolanas en Puerto Rico, Nicolasa, ya estudiada, quien en situación de viudez y con tres hijos huérfanos implora le reconozcan 2 pesos más del Ramo del cacao para no terminar de perderlo todo en su exilio, y Belén que por otra vía más benévola y acomodada, la pensión de vacantes mayores y menores, solicita que no se le obligue a residir en Puerto Rico para poder gozar de dicha gracia. No obstante su caso en el laberinto administrativo y político es sugerente: ella tuvo derecho a gozar de esta dádiva hasta el día en que la provincia de Venezuela se emancipó, Belén tiene 80 años en este momento de su instancia y pide que se le abonen los pagos caídos desde el día de la independencia venezolana hasta el momento, pues alega que por el tratado de paz y reconocimiento de Venezuela por el reino de España ese pago se le ha debido reactivar: «por el tratado de paz con Venezuela en el que se funda la Ley de

55 Ibidem, 2 recto.

56 Ibidem, 2 vuelto.

${ }^{57}$ Ladera, 1990: 25.

58 Instancia de Belén Jerez de Aristiguieta, 3 de julio de 1849, AHN, Ultramar, 1070, exp. 33, núm. 1, 1 vuelto. 
Presupuestos del 26 de mayo de $1835 »^{59}$; Belén aduce que está muy mayor, tiene achaques de salud por lo que desea regresar a Venezuela junto a su hija, que lo único que se lo impide es que de hacerlo, renunciaría a la pensión que solo es posible gozar si se vive en los dominios españoles. Para todas las ayudas, socorros y pensiones - muy especialmente las devenidas del Ramo del cacao- se tiene que residir en los territorios españoles, cualquier otra circunstancia supone la renuncia a ese derecho, lealtad con lealtad se paga.

Se extiende hasta más allá de la segunda mitad del siglo XIX la historia de las mujeres del exilio en Puerto Rico, tratadas ahora como las «beneméritas». Por ejemplo Rosa Franco, que para 1861 vivía en La Coruña, pero había emigrado con su madre, Concepción Pellón, desde Venezuela a Puerto Rico en 1821; o M. ${ }^{\mathrm{a}}$ Antonia Hernández, viuda del capitán de Caballería Juan Bautista Aguirre - muerto en La Guaira-, también del éxodo de 1821; Isabel Ochoa, en este año de 1861 una «anciana achacosa» que se trajo consigo en 1821 «recogida» a la huérfana del brigadier Antonio Tovar, muerto él y sus hermanos por los «disidentes». En la Junta de clases pasivas (1861) se decidió casi en los últimos años de estas gracias, la suerte de las últimas sobrevivientes del exilio. En ella ya se refieren al conflicto como «la Guerra de Independencia» de Venezuela, habiendo una suerte de sentido histórico en el hecho político y militar que se trató durante años como traición, rebeldía, disidencia, etc. Hasta el final, se preveía a la autoridad competente (en la última etapa al corregidor de la capital de Puerto Rico) averiguar «sobre la verdadera procedencia de varias Señoras a quienes le concedieron pensiones como emigradas de Venezuela ${ }^{60}$.

El primer documento sobre el exilio venezolano en Puerto Rico: 17 de julio de 1814

\section{Contexto}

El 22 de junio de 1814 el intendente de Puerto Rico acompaña un oficio de los ministros de Puerto Cabello (Venezuela) sobre la ocupación de Caracas y Valencia por las tropas del rey, cuyo resultado ha sido la migración masiva

59 Ibidem, 1 vuelto.

${ }^{60}$ Pensiones para revisar de las Beneméritas procedentes de Venezuela, 19 de noviembre de 1861, AHN, Ultramar, 1111, exp. 12 bis, núm. 11, 1 recto. 
desde La Guaira para las colonias inglesas de «centenares de personas emigradas, ya comprendidas en los crímenes de guerra de la rebelión, o temerosas de reacciones sangrientas». En el mismo oficio el intendente Ramírez hace referencia de una carta traducida del inglés, donde se habla de los emigrados venezolanos que desde San Tomás han emprendido viaje a Puerto Rico: «800 personas la mayor parte mujeres y criaturas en absoluta desnudez y miseria ${ }^{61}$, por lo que advierte que requiere «para atender al socorro de aquel sexo» un auxilio presupuestario inmediato. Alega que solo los socorros de emigrados empleados y particulares, en asignaciones fijas de «esta clase» son 2.251 pesos fuertes mensuales, pues en tiempos de la regencia el virreinato de México socorrió las Cajas de Puerto Rico. Sin embargo, el intendente no ha tenido noticias de Nueva España desde hace 8 meses y de La Habana desde hace 5 meses.

La ocupación de Caracas y Valencia por las tropas de José Tomás Boves desató una diáspora de ambos bandos. Los partidarios de los patriotas se replegaron por las islas inglesas y holandesas temerosos de la represión que prometía Boves, los leales al rey tenían la posibilidad de Puerto Rico, empero, temerosos también de una guerra sanguinaria donde muchas veces poco importaban las lealtades. Las huestes de Boves operaban por el saqueo y el botín como clave de ánimo táctico, y las mujeres y niños eran el extremo vulnerable de esta dinámica. Por ende quienes confesaban su fidelidad al gobierno del rey sabían que gozarían de mayor protección en Puerto Rico, como país español. Tal y como refieren los informes que poseía el intendente, la mayor parte de esta primera oleada se trataba de mujeres y niños en «absoluta desnudez y miseria» ${ }^{62}$.

El documento que habla de la primera oleada migratoria de exiliados de Costa Firme es una carta procedente de San Tomás del 17 de julio de 1814 donde se informa del arribo de la fragata Palma desde La Guaira. La carta advierte que Boves entró en Caracas el 9 de julio donde «aquella ciudad y La Guaira fueron abandonadas por sus habitantes temiendo las recriminaciones y las venganzas, que tienen bien merecidas, si se deben vengar en los particulares los crímenes de los que mandan ${ }^{63}$. Los que se preparaban para partir a Puerto Rico desde San Tomás, «infelices refugiados», la mayoría mujeres y niños en la más extrema pobreza pues «tuvieron que abandonar sobre el muelle de La Guaira sus equipajes, sus vestidos, todo lo que querían embarcar.

${ }^{61}$ Oficio del Intendente Alejandro Ramírez a los Ministros en Costa Firme, 22 de junio de 1814, AHN, Ultramar, 1070, exp. 18, núm. 1, 1 recto.

${ }^{62}$ Idem.

${ }^{63}$ Carta traducida del inglés para el conocimiento del intendente Alejandro Ramírez, 2 de agosto de 1814, AHN, Ultramar, 1111, exp. 18, núm. 4, 1 recto. 
Los pardos y los zambos apoderados de La Guaira, impidieron el embarque de toda clase de efectos, de modo que hay mujeres literalmente desnudas, y sobre todo criaturas tiernas, sin camisa ni con que comprarla y sin saber cómo han de procurarse lo preciso para existir. Este espectáculo es horrible» ${ }^{64}$.

\section{La lucha entre la Capitanía General y la Intendencia ${ }^{65}$ : La política y el REALISMO PRESUPUESTARIO}

Alejandro Ramírez ${ }^{66}$, «el intendente genial» ${ }^{67}$, en 1814 escribe al rey que ha meditado mucho sobre el tema de la migración de Caracas y lo que más conviene políticamente a la corona. Advierte que todos los emigrados saben que cuentan con ser recibidos en Puerto Rico, salvo aquellos que «se hallan manchado con los horrendos crímenes» pues «esta isla no puede servir de inmunidad, sino de asilo, seguridad y protección como había manifestado en una proclama dirigida a los Españoles de ambos hemisferios en 2 de diciembre de 1811». Aquellos fieles al rey «pueden venir a disfrutar de la generosidad de los Españoles sin comprometimiento alguno» ${ }^{68}$, decía el intendente Ramírez, quien chocará con una cruda realidad presupuestaria donde deberá recoger alguna de sus previsiones iniciales.

El intendente abre «una suscripción» de mil pesos para los «infelices emigrados de Caracas y La Guaira [... como una señal y muestra de fraternal compasión [para que] el amado Soberano de España, el Señor D. Fernando $7^{\circ}$ se interponga poderosamente como un Padre entre sus hijos discordes, para que cesen las calamidades [...] en América» ${ }^{69}$. Una retórica política muy

${ }^{64}$ Ibidem, 1 vuelto.

${ }^{65}$ El primer intendente de Puerto Rico es Alejandro Ramírez (1813); el segundo será el venezolano José Domingo Díaz, desde 1822 hasta 1828; Mariano Sixto, desde 1828 hasta

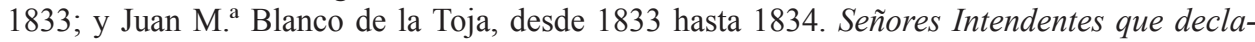
raron las pensiones consignadas sobre los fondos del cacao con expresión de las épocas que desempeñaron la Intendencia de esta Isla, 7 de abril de 1834, AHN, Ultramar, 1070, exp. 11, núm. 5, 2 recto. Por otro documento sabemos del intendente Miguel López de Acebedo, quien seguía de cerca para el lejano año de 1851 los casos de exiliados venezolanos acreedores de las Reales Cajas en la provincia de Venezuela. Situación sobre varios acreedores de las Cajas Reales de Puerto Cabello (oficio del Intendente Miguel López de Acebedo), 26 de mayo de 1851, AHN, Ultramar, 1111, exp. 5, núm. 2, 1 recto.

${ }_{66}$ González, 1978: 9-30.

${ }^{67}$ Zeuske, 2009: 47.

${ }^{68}$ El intendente de Puerto Rico al S.M. sobre los emigrados de Costa Firme, 23 de enero de 1814, AHN, Ultramar, exp. 18, núm. 6, 1 recto.

${ }^{69}$ Ibidem, 1 vuelto. 
sugerente pues para Ramírez como tantos otros funcionarios de alto nivel, es consciente de que el trato dispensado a la diáspora venezolana repercutirá en la «opinión pública» (tal cual se usa la expresión en la documentación, como veremos) del resto de los americanos.

Sin embargo, José Domingo Díaz, que en su momento fue parte del exilio de Costa Firme, asumirá un rol mucho más radical respecto a las ayudas para sus paisanos. Aunque el cacao como rubro seguía entrando a la isla (para 1826) desde San Tomás ${ }^{70}$ y se le seguía pechando el peso fuerte para el Ramo del cacao, el intendente Díaz hizo lo propio, y sin importar el paisanaje se enfrentó con el gobernador y capitán general Miguel de la Torre, otro veterano de la guerra en Venezuela:

He recibido oficios del gobernador y capitán general de esta isla asignando pensiones a varias emigradas de la Costa Firme [... Ya V.E. había observado de algunos meses a esta parte, cuantas ocasiones y motivos se han presentado a la Intendencia y a la Junta de Real Hacienda para hacer abiertas oposiciones a la Capitanía General introducida en materias que la son absolutamente ajenas ${ }^{71}$.

José Domingo Díaz pone en la mesa el tema sensible de la discordia entre las autoridades y la manipulación política que puede surgir, peligrosamente, en detrimento del orden del gobierno del rey en la isla. Asimismo, menciona en el oficio al fantasma del primer grito de independencia en Venezuela, el 19 de abril de 1810, cuyo resultado fue la desintegración de la provincia y una de las más cruentas guerras de la América española. Acusa a la desunión e intrigas mutuas entre la Capitanía General, Audiencia e Intendencia venezolanas como germen de la independencia, advirtiendo que en Puerto Rico podría ocurrir lo mismo de la mano del capitán general, quien quiere otorgar pensiones indiscriminadamente sin atender al juicio de la intendencia.

En el oficio al rey, Díaz es directo respecto a su molestia por la tardanza en un dictamen definitivo sobre este choque de poderes. La mención del 19 de abril de 1810 es ciertamente un atrevimiento, su condición de exiliado venezolano, leal al rey, además de ser uno de los funcionarios que más enfrentó a la causa independentista ${ }^{72}$ desde la Gaceta de Caracas - cuando España recuperó el control de Caracas - lo sitúa en un extraño podio para hablar con autoridad sobre los efectos del desorden institucional, de las con-

${ }^{70}$ Relación de las fanegas introducidas en este Puerto desde la isla inglesa de St. Thomas, 14 de diciembre de 1826, AHN, Ultramar, 1111, exp. 18, núm. 15, 1 recto.

${ }^{71}$ El Intendente José Domingo Díaz sobre las instancias de pensionados y gracias enviadas por el Capitán General de esta Isla, 13 noviembre de 1826, AHN, Ultramar, 1111, exp. 19, núm. 1,1 recto.

72 Gómez, 2013: 281-300. 
traórdenes y desacatos, pues el intendente es claro también cuando arguye que proceder según los deseos del capitán general contraviene la Real Orden del 29 de junio de 1827 en la que se prohíbe saldar cuentas de las Cajas Reales de Caracas con las de Puerto Rico a particulares.

Miguel de la Torre ante los argumentos y acusaciones de José Domingo Díaz reitera las facultades especiales que le licenció el rey para gestionar las pensiones a las emigradas «que por su clase y sexo necesitan con urgencia del paternal auxilio del Soberano» que además juzga que son necesarias «para contribuir a la seguridad de este territorio» ${ }^{73}$. De la Torre también arguye a favor de su causa que Puerto Rico no depende del impuesto del cacao, ni que este socorro grava al real erario pues se paga una vez hecha la recaudación, y remata con una seña meramente moral y otra meramente política cuando dice por un lado que la seguridad de Puerto Rico no depende de la recaudación de ese dinero, de las pensiones, pero «sí depende de ellas la justicia y la humanidad que caracterizan a S.M. y que en diferentes Reales disposiciones tanto a la Intendencia como al gobierno he recomendado expositivamente el socorro de esta clase emigrada ${ }^{74}$; y por otro lado alega que de no tomarse las medidas necesarias respecto a estas emigradas habrá consecuencias, que «si se dejan perecer a estas víctimas de su fidelidad, produciría un mal resultado en la opinión pública $\rangle^{75}$.

El intendente tuerce el brazo disponiendo asignar algunas pensiones (29) según cada caso y aclara al capitán general que estas ayudas son similares a las que se tomaron antes «con toda clase de emigrados de Santo Domingo» tras la revolución haitiana. Para De la Torre esto no es suficiente, que muchas más mujeres «califican su derecho y necesidad de ser socorridas». El intendente resuelve entonces clasificar a las exiliadas venezolanas, entre a) quienes no tenían nada en Costa Firme y emigraron buscando mejor fortuna «sin que se les moviera el menor compromiso» b) las que ningún permiso prestaron a la causa del rey «ni han sido más que entes pasivos» c) aquellas que por su conducta no sean acreedoras a dichos socorros. Es decir, la clasificación del intendente rebaja los méritos de todas las exiliadas venezolanas. La posición del capitán De la Torre era políticamente comprensible. Sin embargo, el intendente demandó prontitud para que en Madrid aclararan cuál de los dos criterios (y poderes) prevalecería. La Secretaría de Ultramar determinó que si

73 Contestación del Capitán General de esta Isla Miguel de la Torre del 29 de mayo de 1828, AHN, Ultramar, 1111, exp. 20, núm. 2, 1 vuelto.

${ }^{74}$ Idem.

75 El Capitán General de Puerto Rico al Consejo de Estado, AHN, Ultramar, 1111, exp. 17, núm. 1, 1 verso, 
en efecto las facultades extraordinarias del capitán general eran para «casos extraordinarios y para medidas y negocios muy distintos de la asignación de estas pensiones», le quitan la atribución de la discrecionalidad al respecto, sería pues el intendente quien se encargue «saber si todas ellas o algunas [pensionadas] han de continuar, prescindiendo ahora de si el capitán general debió, o no, concederlas, podría encargarse al intendente» ${ }^{76}$.

El contraataque del capitán general se basa ahora en un análisis financiero de las Cajas Reales de Puerto Rico, aduciendo que no se ven afectadas por la naturaleza del impuesto y reitera el hecho de que esa medida, en todo caso, fue aprobada por el rey. El Consejo procede salomónicamente y determina que la decisión sobre las ayudas y pensiones del Ramo del cacao deben recaer sobre la Junta Superior de Real Hacienda, conforme al espíritu de las Leyes de Indias y no al arbitrio del capitán general ni del intendente. En Madrid, en 1830, el Consejo expone una sugerente retórica de lealtad, una transferencia simbólica de fidelidad a cambio de su recompensa, que el gobierno de $\mathrm{Su}$ Majestad

... extiende su mano benéfica a varias beneméritas mujeres emigradas de Costa Firme que se hallan en Puerto Rico, las que después de haber perdido sus maridos, hijos o bienes de fortuna, abandonaron sus hogares para dar prueba de lealtad al legítimo Soberano ${ }^{77}$.

A través del hilo documental queda en evidencia la diferencia de criterios entre los dos poderes, a los que finalmente se les interpuso una Junta Superior para dirimir entre ambas expresiones. Lo cierto es que - al menos- la historiografía asume que aunque el capitán general - y gobernador - tenía potestad sobre los asuntos generales de la isla y gozaba de un canal de comunicación directo con el rey, su autoridad cedió espacios a partir de 1813 con el nombramiento del primer intendente ${ }^{78}$. Ciertamente fueron dos visiones, una política, más «humana y moral» y el enfoque pragmático de la Intendencia. Si en efecto admitimos la óptica historiográfica clásica de la disminución de potestades del capitán general ante la Intendencia, también es comprobable el hecho de que en la última y más alta instancia de decisiones sobre las pensiones a los exiliados venezolanos, era sopesado el sentido político del capitán general por tratarse de un actor acaso con más empatía sobre la den-

${ }^{76}$ La Secretaría de Ultramar sobre las facultades del Capitán General de la Isla de Puerto Rico en el pago de pensiones a las emigradas de Costa Firme, 2 de agosto de 1830, AHN, Ultramar, 1111, exp. 17, núm. 1, 4 vuelto.

${ }_{77}$ Ibidem, 8 recto y 8 vuelto.

78 Trías, 1999: 17-18. 
sa problemática social que podría estallar ${ }^{79}$ si se hacía estricto caso al consejo experto y severo del intendente.

\section{CONCLUSIONES}

El Ramo del cacao fue a primera vista una medida de auxilio humanitario del Estado español a los emigrados de Venezuela devenida de un impuesto al comercio del cacao. Analizado con más profundidad, el Ramo del cacao fue una estrategia humanitaria y política hacia el exilio venezolano en Puerto Rico, como dominio español más próximo, sorteada por medio del gravamen de un producto históricamente venezolano, como fue el cacao, columna vertebral del comercio atlántico de la provincia de Venezuela con la metrópoli. A través de este tributo se comprende, por un lado, un proceso administrativo y presupuestario y, por otro, una dinámica meramente política. Ambos nos llevan a concluir varias particularidades: a) el Estado español sufrió una legítima preocupación por sus leales súbditos venezolanos, preocupación que se extendió por 60 años de atención humanitaria y administrativa; b) esta situación develó conflictos entre el poder político y el poder administrativo de dos de las instituciones españolas en América más importantes, la Capitanía General y la Intendencia; c) a través del proceso humanitario, político y administrativo de las pensiones del Ramo del cacao entendimos otra cara de la cruenta guerra de Independencia en Venezuela, el exilio de los leales al rey, los padecimientos de las protagonistas principales de esa diáspora: las mujeres que acarreaban con la viudez, la orfandad y la pobreza circunstancial; d) dentro de esto último pudimos diferenciar las desiguales clases sociales del exilio, de mujeres de la élite social colonial de Caracas y las mujeres del común, en su mayoría viudas de oficiales muertos en la misma guerra; e) asimismo, dentro de esta casuística del exilio, vimos una tabula rasa entre emigrados del mantuanaje y del común, reencontrados como iguales pidiendo el socorro del Ramo del cacao; f) en ese mismo contexto, fue visible que aún sobrevivía algún rastro de los antiguos privilegios de nobles criollos y funcionarios coloniales, cuando se compara la atención que recibieron estos tanto monetaria como burocrática - con los exiliados del común.

De todos los alcances de esta investigación el más revelador es el hecho político y humano de la lealtad, tanto la fidelidad de los súbditos venezolanos que a toda costa abandonan Venezuela por seguir las banderas del rey y la lealtad posterior del Estado español, que en consideración de esa decisión

79 Navarro, 1999: 19-39. 
política y existencial atiende por sesenta años los casos de la diáspora de sus súbditos. Acaso sea este un hecho inédito y sin igual en los procesos de descolonización, emancipación e independencia - y exilio - de un territorio de su metrópoli, evidentemente inédito también por la violencia de esta guerra en particular, que obligó tajantemente a definirse entre dos bandos, lo cual conlleva a adscripciones políticas y existenciales extremas como son perder la libertad, morir y exiliarse - por un sistema de gobierno y su representación sobre todo simbólica - lo que a su vez conduce a una recepción, también particularísima, de la metrópoli colonial para sus — todavía - leales hijos.

\section{BibLiografía}

Cardozo, Alejandro, Los mantuanos en la Corte española. Una relación cisatlántica (1783-1825), Bilbao, Servicio Editorial de la Universidad del País Vasco, 2013.

Ghirardi, María, "Impacto do proceso independentista nos comportamentos matrimoniais de españois em Córdoba", Estudios Migratorios, 6 (Santiago de Compostela, 1998): 125-150.

Gómez, Argenis, Historia de un antihéroe: Obra científica y labor periodística del doctor José Domingo Díaz (1772-1842?), Caracas, Fondo Editorial de Humanidades Universidad Central de Venezuela, 2013.

González, Luis, "Alejandro Ramírez y el establecimiento de la intendencia en Puerto Rico 1813-1816", Luis González Vales, Alejandro Ramírez y su tiempo. Ensayos de Historia Económica e Institucional, San Juan de Puerto Rico, San Juan, Universidad de Puerto Rico, 1978: 9-30.

Ladera, Elizabeth, Contribución al estudio de la aristocracia territorial en Venezuela colonial. La familia Xerez de Aristiguieta. Siglo XVIII, Caracas, Academia Nacional de la Historia, 1990.

Lombardi, Ángel, Banderas del rey (la visión realista de la independencia), Maracaibo, Universidad del Zulia, 2006.

Lynch, John, América Latina, entre colonia y nación, Barcelona, Crítica, 2001.

Marichal, Carlos y Souto Mantecón, Matilde, "Silver and Situados: New Spain and the financing of Spanish Empire in the Caribbean in the Eighteenth Century", Hispanic American Historical Review, 74/4 (Durham: 1994): 587-613.

Mérida, Marco Tulio, Emigración de Venezuela a Puerto Rico tras la Ruptura Colonial, Valencia (Venezuela), T.B. Print CA, 2006.

Naranjo, Consuelo y García, Antonio, "De España a las Antillas. Historia e historiografía de la migración española a Puerto Rico y Cuba en las últimas décadas del siglo XIX y primeras del XX", Migraciones \& Exilios: Cuadernos de la Asocia- 
ción para el estudio de los exilios y migraciones ibéricos contemporáneos, 1 (Madrid, 2000): 161-196.

Navarro, Jesús, “Grupos de poder y tensiones sociales en Puerto Rico durante la crisis del imperio (1815-1837): un intento de síntesis", Jesús Navarro, Puerto Rico a la sombra de la independencia continental (Fronteras ideológicas y políticas en el Caribe, 1815-1840), Sevilla, CSIC, 1999: 19-39.

Ruiz de Gordejuela, Jesús, La expulsión de los españoles de México y su destino incierto, 1821-1836, Sevilla, CSIC, 2006.

Trías, José, Historia Constitucional de Puerto Rico, San Juan, Universidad de Puerto Rico, 1999, vol. I.

Yacou, Alain, "La stratégie espagnole d'éradication de Saint-Domingue français, 1790-1804", Paul Butel y Bernard Lavallé (coord.), L'Espace Caraïbe. Théâtre et Enjeu des Luttes Impériales (XVIe - XIXe Siècle), Bordeaux, Maison des Pays Ibériques, 1996: 277-293.

Zeuske, Michael, "Regiones, espacios e hinterland en la independencia de Venezuela. Lo espacial en la política de Simón Bolívar", Revista de las Américas. Historia y presente, 1 (Valencia, 2003): 39-58.

Zeuske, Michael, "Las capitanías generales de Cuba y Puerto Rico en el «Gran Caribe», 1808-1812”, Manuel Chust e Ivana Frasquet (eds.), Los colores de las independencias iberoamericanas. Liberalismo, etnia y raza, Madrid, CSIC, 2009: 21-48.

Fecha de recepción: 17 de julio de 2019.

Fecha de aceptación: 17 de enero de 2020.

\section{Ramo del cacao. The exile, poverty and loyalty of Venezuelan immigrants in Puerto Rico, 1813-1873}

The aims of the study were to examine the testimonies of Venezuelan fidelity to the Crown, the causes of the hurried large-scale exile, as well as the political and administrative conditions with which this diaspora was received in Puerto Rico. The sources were the collection of the Archivo Histórico Nacional (Madrid) de Ultramar (1070 and 1111) which contains files, letters and memorials of exiles, press and official documents. The results demonstrate Spain's commitment to loyal Venezuelan vassals, the tragedy and vulnerability in particular of the women of the diaspora, and the political-administrative mechanisms (Ramo del Cacao) used by Spain to deal with the social problem of the mass Venezuelan migration to Puerto Rico.

KeY words: Ramo del Cacao; war; diaspora; exile; Costa Firme; Venezuela. 
